\title{
The protective role of physical activity in different pathologies
}

\author{
A Gradilone \\ From de Senectute: Age and Health Forum \\ Catanzaro, Italy. 5-7 December 2009
}

The protective role of physical activity in different pathologies has been shown in numerous scientific studies on the general public and especially among older adults [1].

Physical activity has been shown to be effective in reducing the onset of several chronic pathologies, such as cardiovascular diseases, hypertension [2], diabetes, osteoporosis, obesity [3]. and neoplastic diseases, also it helps to diminish depression and anxiety by maintaining a balanced mood.

Exercise activates the metabolic system in order to supply energy, in a trained organism it increases the use of glucose from part of the muscle which increases or diminishes the onset of hyperglycemia, typical of diabetes [4].

Lipid metabolism is favorably influenced by the decrease of the lipoprotein at low density LDL by increasing the HDL [5].

An exercise that burns out $4-7 \mathrm{Kcal} /$ minute reduces cardiovascular mortality rate in men and women, no matter the age group. Increasing the intensity of muscle activity, the risk of mortality rate in cardiovascular diseases tend to progressively diminish [6].

Regular physical activity has also significantly been shown to decrease the risk of colon and breast cancer [7].

The mechanical stimulus produced by physical activity promotes bone remodelling. In particular, physical activity transfers stimulus to the bone in two ways: directly to the body's weight on the skeleton, and indirectly through muscle activity [8].

Published: 19 May 2010

Department of Sports Medicine, ASP Cosenza, Castrovillari, 87012, Italy
References

1. Warburton DE, et al: Health benefit of physician activity: the evidence. CMAJ 2006, 174:801-9.

2. Fagard $\mathrm{RH}$, Cornelissen VA: Effect of exercise on blood pressure control in hypertensive patients. Eur J Cardiovasc Prev Rehabil 2007, 14:12-7.

3. Jakicic JM, Otto AD: Physical activity considerations for the treatment and prevention of obesity. Am J Clin Nutr 2005, 82:226S-229S.

4. Jeon C, et al: Physical activity of moderate intensity and risk of type 2 diabetes. Diabetes Care 2007, 30:744-52.

5. Kodama $\mathrm{S}$, et al: Effect of aerobic exercise training on serum levels of high-density lipoprotein cholesterol: a meta-analysis. Arch Intern Med 2007, 167:999-1008.

6. Noda $\mathrm{H}$, et al: Walking and sports participation and mortality from coronary heart disease and stroke. J Am Coll Cardiol 2005, 46:1761-7.

7. McTiernan A, et al: Recreational physical activity and the risk of breast cancer in postmenopausal women. JAMA 2003, 290:1331.

8. Borer KT, Wuorinen E, Ku K, Burant C: Walking intensity for postmenopausal bone mineral preservation and accrual. Bone. 2007, 41(4):713-21.

doi:10.1186/1471-2318-10-S1-L36

Cite this article as: Gradilone: The protective role of physical activity in different pathologies. BMC Geriatrics 2010 10(Suppl 1):L36.
Submit your next manuscript to BioMed Central and take full advantage of:

- Convenient online submission

- Thorough peer review

- No space constraints or color figure charges

- Immediate publication on acceptance

- Inclusion in PubMed, CAS, Scopus and Google Scholar

- Research which is freely available for redistribution

Submit your manuscript at www.biomedcentral.com/submit
C Biomed Central 